\title{
VALIDATING ACHIEVEMENT TESTS OF THE ENGLISH COURSE: THE USE OF THE ENGLISH PART
}

\author{
Assoc. Prof. Dr. Dileta Jatautaitė \\ General Jonas Žemaitis Military Academy of Lithuania
}

Joana Aleksandrovič

Mykolas Romeris University

\begin{abstract}
This study advocates for the central quality of the language tests and their validity and aims to investigate the content validity of the use of the English part of the achievement tests administered to the first-and second-year students of General Jonas Žemaitis Military Academy of Lithuania. The tests were given in the form of the final examination of the English language course in order to find out if the papers' content corresponded to the descriptors of the European language levels specified in the Common European Framework of Reference for Languages and the Europass on which the course syllabus was based. Seeking to examine the content validity, the study analyses the papers in terms of the task types and linguistic-grammatical and lexical-knowledge tested. The analyses of the papers revealed that although both open and semi-open tasks and closed tasks were present in the papers and specifications, the former were dominating for being more effective. Some of the papers lacked certain grammatical and lexical aspects to be tested which were mentioned in the specifications, such as pronouns, relative clauses, conditional clauses, modals, derivatives and collocations. The syntactic competence was tested in all the papers. As a result, the content validity of these papers can be partially supported, though in a general view, it can be inferred that the papers had the content validity, i.e. they measured what is supposed to be measured. Therefore, these findings suggest that the content of the achievement tests might be revised and may contribute to further research of validity in language testing.
\end{abstract}

Key words: test validity, competence, achievement tests, specifications, descriptors, qualitative assessment.

Introduction. The communicative language approach has resulted in the need to test the communicative language ability "which can be described as consisting of both knowledge, or competence, and the capacity for implementing, or executing that competence in appropriate, contextualized communicative language use' (Bachman 1990: 84). It should be pointed out that the communicative 
language competence gave rise to the communicative language approach in the domain of language testing. It is generally acknowledged that language tests have a sound significance in the society - not only in the educational context but also when applying for a job. There are plenty of multifarious language tests with specific goals such as progress, proficiency or achievement tests which are the object of the present study. The achievement test purports to measure what students have learned over a fixed period of time and 'how individuals should proceed through the program, or how well they are attaining the program's objectives' (ibid. p. 70). According to the Routledge Encyclopedia of Teaching and Learning: 'the content of achievement tests is chosen with reference to a clearly defined syllabus, so only the material and skills on that syllabus are tested. $\langle\ldots\rangle$ the focus is on the average performance of the group, and this information is used to decide whether changes (if any) [to the syllabus] need to be made' (Banerjee in Byram 2004: 3).

It has been traditionally admitted that a 'good', 'meaningful' and 'useful' test is required to feature the following key principles: validity, reliability, practicality and washback effect. Due to the fact that the paper's central concern, as the title entails, is validity, the theories concerned with it are discussed in greater detail after the rest of the mentioned facets are presented. Nevertheless, each of the criteria is important to the test.

The aim of the research is to investigate the content validity of the use of the English part of the achievement tests administered to the first- and second-year students of General Jonas Žemaitis Military Academy of Lithuania. The tests were given in the form of the final examination of the English language course in order to find out if the papers' content corresponded to the descriptors of the European language levels specified in the Common European Framework of Reference for Languages and the Europass on which the course syllabus was based.

The object of the research is validating the achievement tests of the English course through the use of the English part.

\section{In order to achieve the aim, the following tasks were set:}

1. To examine the content of the use of English as a part of the achievement tests administered to the first- and second-year students of General Jonas Žemaitis Military Academy of Lithuania in the context of the semester examination session of the English language course. The tests were compiled by the instructors of the course.

2. To investigate whether the use of the English part of the achievement tests test what they are intended to test.

Research methodology and methods: literature and document analysis, qualitative testing measurement of reliability and validity, the concept of the socalled washback.

Language testing has become a potential area for linguistic research and 
interest in recent years, hence an advanced pleiad of scholars have started exploring peculiarities concerning language testing and its theories. The majority of scholars have defined reliability as the quality of test scores illustrating the steadiness of results (Bachman 1990; Lado 1964; Pilliner 1968). In other words, reliability is the '[c]consistency of measurement of individuals by a test' (McNamara 2000:136). The 'complex' relationship between reliability and validity is persistently emphasized (Alderson et. al 1995; Bachman 1990; Lado 1964; Heaton 1991; Underhill 1982, Jatautaite, Kazimianec, Aleksandrovič 2019). Besides, Underhill (1982:17) indicates 'the influence' of practicality, i.e. another criterion referring mainly to the external factors as time which is 'precious' for the test 'must test in one hour what has been learned in a month or a year or five years' (Lado 1964:20), and money related to both rating of scorers and test publication. As Bachman \& Palmer (1996:35) maintain, a practical test does not 'exceed the available resources at any stage in test development'. Moreover, although it was claimed that 'testing controls teaching' (Candlin 1993:vii), Alderson et al. notice that language testing is not 'dependent upon' teaching and is not to 'respond to every whim of pedagogic fashion' (1995:227).

In addition to reliability, the concept of the so-called washback effect cannot be disregarded. As the researchers claim, this notion is the effect which a test or an examination may have on the classroom teaching (McNamara 2000; Alderson et. al 1995, Johnson 1982; Jatautaitè, Kazimianec (2019), Wall \& Alderson 1995). They note the twofold nature of this effect: positive and negative. A negative washback gained more popularity and is constantly being discussed, whereas a positive washback is only mentioned without much scrutiny. Wall \& Alderson (1995:199) identify that a positive washback is a 'co-operation between textbook and exam' which determines 'teaching the textbook' rather than 'teaching to the exam' directly referring to as a negative washback (Johnson 1982:70). Probably that is why Alderson et al. suggests that the tests should be innovated each year 'to avoid any fossilization of the test' and simultaneously 'to improve content validity' (1995: 228).

As regards the most crucial and fundamental quality of any test, i.e. validity, it is proposed that the test validity is an indicator of whether the test measures what it is intended to measure (Alderson et. al 1990; Lado 1964; Heaton 1991), whereas Cumming points out another aspect to be taken into account. When dealing with the test validity, one should know "what any one test actually does under different conditions, (...) how well the intentions and functions of the test correspond' (1995:4-5). It is essential to stress upon the complex nature of validity which can be classified in a multifold way. In other words, there are different types of validity. However, some theorists find it problematic and it is claimed that some of them perceive different types of validity 'as aspects of a unitary concept of validity that subsumes all of them' or 'as complementary types of evidence' (Bachman 1990:236-243). To that matter, Cumming suggests that instead of 'enumerating' the 
types of validity, the idea of construct validity can stand as 'the single, fundamental principle that subsumes various aspects of validation' (1995:5). However, as far as validity itself is concerned, Alderson et al. supposes the more types of validity a test has, the better it is (1995:171).

However, this research paper focuses mainly on one validity type - content validity - an important, though, complex methodology term, which might be referred to as 'rational validity' as well (ibid.). The scholars have agreed upon that in order to feature content validity, a test must coincide with its intention and its content must be representative of the domains it seeks to test (Alderson et al. 1995; Bachman 1990; Heaton 1991; Cronbach 1970; Pilliner 1982; Litwin 1995). Pilliner (1968), Litwin (1995) and Underhill (1982) highlight that a content validity cannot be quantified. It 'demands instead logical analysis and subjective judgement' and is 'a qualitative assessment of the extent to which the test probes ultimate objectives' (Pilliner 1968:32-33). Consequently, it is 'an overall opinion (...) of judges' (Litwin 1995:35) who decide whether the test 'is a test of what it says it is' (Davies 1982:12). Alderson et al. refers to 'judges' as 'experts' who 'analyse the content and compare it with a statement of what the content ought to be' (1990:173). This 'content statement' can be 'the test's specifications', 'a formal teaching syllabus or curriculum', or 'a domain specification' (ibid.). In the case of the present study, it is the English language course syllabus which is based on the descriptors of the European language levels given by the Europass and specified by the Common European Framework of Reference for Languages.

The focus of this study is to investigate whether the use of the English part of the achievement tests test what they are intended to test. In other words, it addresses such questions as to what extent the examination papers possess content validity and how well their content reflects the specifications of the descriptors of the European language levels listed by the Europass.

\section{Data and Methods}

In order to analyze content validity of the use of the English part of the achievement tests, this study made use of eight achievement tests administered during the examination session to the first- and second-year students. The sample consisted of four tests of the academic year 2018/2019 and four tests of the academic year 2019/2020. The procedure involved the investigation of the papers in terms of the included task types and according to the linguistic knowledge tested. The descriptions of the task types were taken from Hughes (2003) and Heaton (1990). All the tasks used in the achievement tests were classified by the task types. As to linguistic knowledge, two categories were distinguished, namely, grammatical and lexical. The syntactic category as such was not marked, since to accomplish every task the basic knowledge of syntax was necessary.

Each occurrence of the task type was firstly identified in the papers, then 
highlighted and marked in the table. If a task was the combination of two types, each of them was indicated in the table.

Each individual linguistic point identified in the papers was ascribed to the relevant linguistic category. All observed linguistic points were reported in the tables and compared with the specifications of the descriptors of the European language levels given by the Europass. The instances were also counted in order to reveal whether their occurrence was changing through the years or has remained the same.

\section{Results and Discussion}

\section{The Analysis of the Achievement Tests According to the Task Types}

The analysis firstly examines the task types included in the papers. Table 1 below indicates the distribution of the task types across eight achievement tests in the sequence of decreasing frequency.

Table 1. Task types included.

\begin{tabular}{|c|c|c|c|c|c|c|c|c|}
\hline Term/Year & $\begin{array}{c}2018 \\
\text { Autumn } \\
\text { Task types }\end{array}$ & $\begin{array}{c}2018 \\
\text { Autumn } \\
\text { Year 2 }\end{array}$ & $\begin{array}{c}2019 \\
\text { Spring } \\
\text { Year 1 }\end{array}$ & $\begin{array}{c}2019 \\
\text { Spring } \\
\text { Year 2 }\end{array}$ & $\begin{array}{c}2019 \\
\text { Autumn } \\
\text { Year 1 }\end{array}$ & $\begin{array}{c}2019 \\
\text { Autumn } \\
\text { Year 2 }\end{array}$ & $\begin{array}{c}2020 \\
\text { Spring } \\
\text { Year 1 }\end{array}$ & $\begin{array}{c}2020 \\
\text { Spring } \\
\text { Year 2 }\end{array}$ \\
\hline Verb completion & + & + & + & + & + & + & + & + \\
\hline Cloze & & & + & + & + & + & + & + \\
\hline Word formation & + & + & + & + & + & + & + & + \\
\hline Transformation & & & + & & + & & & + \\
\hline Multiple choice & + & + & + & + & + & + & + & + \\
\hline Matching & + & + & + & + & + & + & + & + \\
\hline Banked gap-filling & + & + & + & + & + & + & + & + \\
\hline
\end{tabular}

Although Table 1 shows that the use of the English part in all of the papers consisted of seven tasks, all of the tests employed one multiple choice task on vocabulary and a multiple choice task on the use of the tenses which was counted as one task type.

Known as the most traditional task type, verb completion was present in all the papers. The task tested students' knowledge of the English verb system, since it is by far more complex in comparison to that of the Lithuanian one which has no perfect tenses. As a result, this task is extremely indicative of how well a student knows English and probably its presence is inevitable in the setting of the English achievement tests. As this testing technique is said to be suggestive and useful, another test format is also popular in the testing field. In particular, a cloze test which was included in the majority of the papers, more precisely, in six of them. It should be noted that the cloze activity is regarded as very effective by most theo- 
rists for this task type is holistic, that is the components of language (grammar and vocabulary) are tested simultaneously (Johnson 1982; Madsen 1983). So, this task type reflects how students feel the language and how successfully they are able to operate it. However, it may seem strange that after the continual presence, this task type was not previously included. It appears that the effectiveness of this task type was probably questioned. Instead, there is quite a wide range of other types such as a multiple choice or banked gap-filling. It is true that 'the more methods a test employs, the more confidence we can have that the test is not biased towards one particular method' (Alderson et al. 1995:45). Perhaps the exclusion of this task was just a manoeuvre to 'reduce the predictability of the test's format which can easily affect teaching' (ibid. p. 46). Time-consuming marking which provokes 'lengthy discussions on the appropriacy of different answers' might be the reason as well (ibid.).

The activity on word formation was also included in all of the tests under investigation. The tendency of putting this task into the paper is systematic because, according to Heaton, the "word formation items are useful for classroom testing' (1991:60). It shows to what degree learners 'are able to manipulate words morphologically in such a way that it fits a given sentence context' (Moss 2017: 151).

As to the transformation procedure, it was employed in three papers. The task reverberates students' knowledge of syntax and grammatical structures as the 'ability to transform sentences correctly' is checked (Harmer 1987:64). However, as the findings illustrate, it is not so frequent in the tests under scrutiny. This may be due to its tiny 'deficiency', i.e. the lack of context which is intrinsic dealing with the smallest linguistic units. However, it is rather disappointing that this type of task has not gained much approval despite being rather effective in testing students' competence. It cannot be claimed too simple for the examination, but it is definitely the least applicable task type in this setting. The main reason for its 'unpopularity' would be 'impracticality', i.e. time-consuming marking and disputes about possibilities of correct answers.

As far as the question of context is concerned, the following task type, i.e. multiple choice employed in the papers is maintained to be "the uncontextualized method of assessing grammar' (Rea 1982:45). Hence, the 'multiple choice tests throw students into a confusing maze of unlikely error, into a situation where far more language is wrong than right' (Jones \& Wheeler 1983:261). On the other hand, if they are well-written, these tasks enable testees to show their competence 'to control very fine distinctions in vocabulary, grammatical structures, phonology, or comprehension of content' (Douglas 2010:50). Another probable advantage why it is systematically included is scoring which is not time-consuming.

Although this method is rather inadequate and invalid to assess the ability to actually use the language, it allows to use 'quite subtle aspects of language knowledge, including as well more comprehensive aspects of language use such as 
rhetorical organization, pragmatic knowledge, or inferencing ability' (ibid. p. 51).

As to the word matching task, which is also a variation of selected response tasks as much as a multiple choice, it aims to test the knowledge of collocations throughout the tests. However, a great care should be given to develop such a task as sometimes more collocates are possible to form than was implied.

In the final example of the task types found in the tests, a banked gap-filling task, which was employed in all the tests, '[e]ach of the missing words or phrases is included in a list which is presented on the same page as the gap-filling text' (Alderson et al. 1995:54). Although it could be posited that this task type does not challenge a test taker since the provided bank serves as a key, students have found it rather challenging. It does not merely aim to assess the use of correct linguistic forms but the syntactic competence of testees. Admittedly, it purports to measure the word order concentrating mostly on the level of the noun, verb and adverb phrase.

Overall, the results yield significant evidence that open and semi-open task types rather than the closed ones were prevailing in the papers for being the most optimal and reliable for effective testing of the appropriacy of the actual language use. Although when communicating in real life situations we do not answer multiple choice questions, this task type is rather prevalent and its inclusion might be reconsidered.

\section{The Analysis of the Achievement Tests According to the Linguistic Competence}

This section looks at the linguistic competence grammatically and lexically. It should be pointed out that with regard to the students' proficiency in the matters of syntax, i.e. word order, ability to join coordinating and subordinating clauses into simple or composite sentences, was practically tested in all the papers since the basic knowledge of syntax was necessary to accomplish every task. Thus, the syntactic competence tested will not be discussed in a separate section.

\section{Grammatical Competence}

Table 2 presents the grammatical competence tested in the papers. The first column illustrates distinguished grammatical aspects, whereas the rest of the columns inform about the occurrences of individual items in the papers. Grammatical competence was divided into the following two groups: the first four aspects deal with the English verb system, whereas other three aspects are of the functional character. 
Table 2. Grammatical competence tested.

\begin{tabular}{|c|c|c|c|c|c|c|c|c|}
\hline $\begin{array}{c}\text { Grammatical } \\
\text { competence }\end{array}$ & $\begin{array}{c}2018 \\
\text { Autumn } \\
\text { Year 1 }\end{array}$ & $\begin{array}{c}2018 \\
\text { Autumn } \\
\text { Year 2 }\end{array}$ & $\begin{array}{c}2019 \\
\text { Spring } \\
\text { Year 1 }\end{array}$ & $\begin{array}{c}2019 \\
\text { Spring } \\
\text { Year 2 }\end{array}$ & $\begin{array}{c}2019 \\
\text { Autumn } \\
\text { Year 1 }\end{array}$ & $\begin{array}{c}2019 \\
\text { Autumn } \\
\text { Year 2 }\end{array}$ & $\begin{array}{c}2020 \\
\text { Spring } \\
\text { Year 1 }\end{array}$ & $\begin{array}{c}2020 \\
\text { Spring } \\
\text { Year 2 }\end{array}$ \\
\hline Verb forms & 25 & 25 & 20 & 26 & 29 & 20 & 20 & 35 \\
\hline Modals & & 1 & 4 & & & 5 & 2 & 2 \\
\hline Conditionals & & 2 & 13 & & 2 & & 1 & 1 \\
\hline Articles & 1 & 2 & 6 & 7 & 2 & & 3 & 2 \\
\hline Prepositions & 2 & 3 & 6 & 5 & 3 & 4 & 8 & 6 \\
\hline $\begin{array}{c}\text { Relative } \\
\text { clauses }\end{array}$ & 1 & & & & & & 6 & \\
\hline
\end{tabular}

Firstly, it should be pointed out that the verb forms were tested in eight papers. The previous part of the analysis dealing with the task types indicated that the tasks on the verb forms were fixed into the context of the achievement tests. Hence, the number of the items testing the ability to use correct tenses, (both active and passive) verb forms and verb patterns is by far the leading one. The knowledge of relevant verbs patterns was checked throughout four papers and this is suggestive of integrating more items related to this aspect as the use of verb patterns illustrates how well the testees operate the language. Modals appeared in six papers. However, the number of the items testing modals is quite fluctuating. The system of modal verbs in English is rather complex for foreign learners due to their polyfunctionality: 'individual forms can be used to express a number of meanings' morphologically, lexically, syntactically, or via intonation (Foley\&Hall 2008:174). For example, even three modal verbs are suitable in the following sentence: 'When I went into 'Bobby's World' I had no idea it (to be) success' (Year 2, Autumn 2019).

Overall, epistemic modals (possibility and probability) prevailed, though there were some instances which required to express obligation and permission (non-epistemic modality), e.g. 'You must/could/mustn't have told me you were going to be late for lunch. Why didn't you?' (ibid.).

The knowledge of conditional patterns was measured in five papers. Again, the fluctuating tendency can be observed since the Year 1, Spring 2019 test employed thirteen items, while the Year 1, Spring 2020 test had only one. It is evident that the patterns of conditionals in English are more complicated than those of the Lithuanian language, however, they are the indicators of how proficient students' knowledge of English is. The first and third types of conditionals were mostly tested, e.g. 'If it can engage me, there is hope it (to do) the same for my mates' (Year 1, Spring 2019).The so-called functional words tested in the papers are described as well. It often seems that 'the smallest English words present the largest problems for nonnative learners of English (Bander 1978: 40).

As Table 2 presents, typically, the number of items measuring the use of 
articles fluctuated from one to three. It is generally known that the article is a peculiar feature of the English language causing difficulties for non-native English learners who have no corresponding article system. Consequently, articles are indicators of 'language proficiency (...) because acquisition involves a composite of highly complex linguistic factors as well as semantic and discourse-related factors' (Cumming \& Mellow 1995: 88). The analyzed papers test mainly the use of the indefinite and definite articles with countable and uncountable nouns, e.g. 'It is the busiest Canadian port on the Great Lakes and is __ major centre for banking, manufacturing and publishing' (Year 2, Spring 2020). However, the number of instances is rather poor and debatable since the question whether those two items really show the student's knowledge may arise. Of course, there is an indirect testing of the article in writing assignments, however, they go beyond the present research aim.

The competence to use prepositions was also tested in all the papers. As Table 2 indicates, the number of items varied, however, it was increasing throughout the papers. Prepositions are claimed to be troublesome for non-native learners: 'sometimes they can be used interchangeably (...) because a single preposition can be used to express several different ideas' (Bander 1978:40).

Furthermore, Table 2 illustrates that just two papers included the items on relative clauses, simultaneously checking the testees' grammatical knowledge of relative pronouns. Evidently, the content of the tests is majorly oriented to the verb system.

\section{Lexical Competence}

The previous section described grammatical competence tested in the test papers, whereas this section deals with lexical competence the findings of which are presented in Table 3.

Table 3. Lexical competence tested.

\begin{tabular}{|c|c|c|c|c|c|c|c|c|}
\hline $\begin{array}{c}\text { Lexical } \\
\text { competence }\end{array}$ & $\begin{array}{c}2018 \\
\text { Autumn } \\
\text { Year 1 }\end{array}$ & $\begin{array}{c}2018 \\
\text { Autumn } \\
\text { Year 2 }\end{array}$ & $\begin{array}{c}2019 \\
\text { Spring } \\
\text { Year 1 }\end{array}$ & $\begin{array}{c}2019 \\
\text { Spring } \\
\text { Year 2 }\end{array}$ & $\begin{array}{c}2019 \\
\text { Autumn } \\
\text { Year 1 }\end{array}$ & $\begin{array}{c}2019 \\
\text { Autumn } \\
\text { Year 2 }\end{array}$ & $\begin{array}{c}2020 \\
\text { Spring } \\
\text { Year 1 }\end{array}$ & $\begin{array}{c}2020 \\
\text { Spring } \\
\text { Year 2 }\end{array}$ \\
\hline Derivatives & 8 & 11 & 11 & 10 & 10 & 7 & 10 & 10 \\
\hline Collocations & 10 & 14 & 11 & 14 & 8 & 12 & 10 & 12 \\
\hline $\begin{array}{c}\text { Relatedness } \\
\text { of meaning: } \\
\text { inclusion }\end{array}$ & 21 & 11 & 17 & 15 & 11 & 18 & 16 & 12 \\
\hline $\begin{array}{c}\text { Relatedness } \\
\text { of meaning: } \\
\text { exclusion }\end{array}$ & 7 & 4 & 7 & 8 & 2 & 4 & 9 & 6 \\
\hline Idioms & 8 & 1 & 3 & & & 1 & 5 \\
\hline
\end{tabular}


Students' competence to build a new word belonging to the same word family was measured in the papers which employed a task on the word formation. The majority of new words had to be built by the means of suffixation. The following Latin and native suffixes were tested most frequently: adjective (-al), noun (-tion, -er), adverb (-ly). Apart from suffixation, several cases of sound interchange were noticed, e.g. '(...) this is the place where she would like to spend her (live) ' (Year 1, Autumn 2019); prefixation, e.g. 'It's very difficult to (entangle) fact from fiction in what she's saying' (Year 2, Autumn 2018).

Additionally, in the Year 1, Spring 2019 test, one item had to be formed with the help of suppletion, e.g. ' $(\ldots)$ the weather is really getting (bad) than ever'. Generally, it is clear that the mastery of the word formation reflects the testees' level of vocabulary range and their knowledge of prefixes and suffixes.

The knowledge of collocations was tested throughout eight papers. Most often the testees were required to think of suitable collocates for nouns and nouns or nouns and adjectives: for example, 'It was decided that this was a

target as the mines were causing real menace to the Royal Navy and there was little risk of civilian casualties' (Year 2, Spring 2020).

However, it should be admitted that the test cannot always precisely and consistently measure students' competence of the use of collocations, but it can be presented more thoroughly in a writing or speaking task which would be a different area of research.

Furthermore, the items of the two types of the relatedness of meaning in English, inclusion (hyponymy and synonymy) and exclusion (complementation and contiguity) have been observed in every paper, for example, 'Households have been shrinking / skyrocketing / mounting up in size but increasing in number' (Year 1, Spring 2019); 'The research has had a number of (= by-products) in the development of high-tech gadgets' (Year 2, Autumn 2019). Hence, it seems clear that the tests tend to integrate a rather solid number of the items that check students' knowledge of the English vocabulary.

The final competence in the table refers to the use of (both semantically transparent and opaque) idioms, which were tested in six papers, for example, 'Management often cast an eye / keep an eye / turn a blind eye / see eye to eye to bullying in the workplace' (Year 2, Autumn 2018). Their competent and correct use usually indicates a sound command of English as they are ascribed to figurative language and require inferring the meaning from the context. Although the number of the items varied, they are necessary for a valid foreign language vocabulary assessment. 


\section{The Results of the Research}

A tentative conclusion based on the findings of this study is that, to a certain extent, the content of the use of the English part of the achievement tests measured the skills which are purported to be measured according to the descriptors of the European language levels.

Although the specifications indicate that both open and closed task types are possible in the use of the English part, open and semi-open ones dominated for being integrative, thus, more effective. Though, in some papers closed task types were consistently employed as well so as to vary the range of tasks. As to the linguistic knowledge tested, it can be concluded that the content of the tests covered almost all the requirements. With regard to the grammatical competence, the results demonstrated that some papers lacked the items testing the students' ability to use modals, conditionals and relative clauses. The findings also yielded that both lexical and syntactical knowledge was tested in all the papers. However, according to the findings, adding more items that test idiomatic expressions could be taken into account.

The findings suggest that it would be a valid reason to revisit the specifications and adjust them to the changing linguistic reality in Lithuania by expanding the variety of task types and topics and diversifying grammatical, lexical and syntactical patterns tested. In addition, the gathered evidence motivates to consider the possibility of internal changes in the course syllabus: the achievement tests could adopt some amendments considering the idea that the written assignments pertain probably more to the actual use of language.

In conclusion, the analysis collectively suggests that a more thorough and systematic attention needs to be given in the future to the issue of the content of the achievement tests. The present findings may also have some pedagogical implications and possibly contribute to further research of validity in language testing. 


\title{
PASIEKIMŲ TESTŲ VALIDUMAS ANGLŲ KALBOS KURSE: TAIKYMAS VERTINANT ANGLŲ KALBOS İGŪDŽIUS
}

\author{
Doc. dr. Dileta Jatautaitė \\ Generolo Jono Žemaičio Lietuvos karo akademija \\ Joana Aleksandrovič \\ Mykolo Romerio universitetas
}

\section{Santrauka}

Šio straipsnio tikslas - nustatyti pasiekimų testų turinio validumą, kuris rodo, ar anglų kalbos pasiekimų testų kalbos (gramatikos ir žodyno) vartojimo dalies turinys atitinka programoje numatytus reikalavimus. Tyrimo tikslams pasiekti buvo išanalizuoti aštuoni kalbos vartojimo testai (2018-2019 ir 2019-2020 m. m.). Jie buvo nagrinejjami dvejopai: pagal užduočių tipus ir pagal tikrinamus gebèjimus (gramatiniai, leksiniai, sintaksiniai). Analizè atskleidè, kad atvirojo ir pusiau atvirojo tipo užduotys buvo taikomos gana dažnai. Tačiau tam tikros uždarojo tipo užduotys buvo tendencingai įtraukiamos į testus. Tyrimo metu nustatyta, kad daugumos nagrinètų testų turinys sutampa su egzamino programa. Tačiau reikia pabrèžti, kad kai kuriuose testuose trūko tokių tikrinamų gebẻjimų kaip ịgūďių taisyklingai vartoti modalinius veiksmažodžius, sąlygos sakinių struktūras, santykinius sakinius, idiomas. Rezultatai parodè, jog sintaksiniai ryšiai ir konstrukcijos buvo gana plačiai testuojamos, nes atlikdami kiekvieną užduotị testuojamieji turejjo pritaikyti elementarias sakinių konstrukcijos žinias. Vis dẻlto anglų kalbos pasiekimų testų kalbos vartojimo dalies turinys apskritai turètų sulaukti daugiau dèmesio, todèl vertètų egzamino programoje padaryti tam tikrus pakeitimus ir ją patobulinti.

Reikšminiai žodžiai: testo validumas, kompetencija, pasiekimų testai, specifikacija, deskriptorius, kokybinis vertinimas. 


\section{AUTORIŲ LYDRAŠTIS}

Autoriaus vardas, pavardè: Dileta Jatautaitè

Mokslo laipsnis ir vardas: socialinių mokslų daktarè, docentė

Darbo vieta ir pareigos: Generolo Jono Žemaičio Lietuvos karo akademijos docentè

Autoriaus mokslinių interesų sritys: psicholingvistika, glotoedukologija, edukologija, tradiciniai ir netradiciniai kalbų mokymo metodai bei metodologija, psichoedukologiniai kalbų mokymo bei išmokimo pagrindai

Telefonas ir el. pašto adresas: (8 5) 210 3560; dileta.jatautaite@mil.lt

Autoriaus vardas, pavardė: Joana Aleksandrovič

Mokslo laipsnis ir vardas: lektore

Darbo vieta ir pareigos: Mykolo Romerio universitetas, lektore

Autoriaus mokslinių interesų sritys: akademinès (anglų) kalbos mokymas, kalbos testų teorija ir praktika, literatūra anglų kalba (Didžioji Britanija, JAV, Kanada, Australija, Airija)

Telefonas ir el. pašto adresas: joana.university@gmail.com

\section{AUTHORS' COVER LETTER}

Author's name and surname: Dileta Jatautaitè

Academic degree and name: Associate Professor, Doctor

Workplace and position: General Jonas Žemaitis Military Academy of Lithuania

Author's research interests: psycholinguistics, glotoeducology, neurolinguistics, traditional and non-traditional language teaching methods and methodology, psycho-educational basis in language learning and acquisition.

Telephone and e-mail address: +370 5210 3560; dileta.jatautaite@mil.lt

Author's name and surname: Joana Aleksandrovič

Academic degree and name: Lecturer

Workplace and position: Mykolas Romeris University

Author's research interests: academic English teaching, language testing, theory and practice, English (British, American, Canadian, Australian and Irish) literature.

Telephone and e-mail address: joana.university@gmail.com 


\section{References}

1. Alderson, J. Ch., C. Clapham \& D. Wall. (1995). Language Test Construction and Evaluation. Cambridge: CUP.

2. Bachman, L. F. (1990). Fundamental Considerations in Language Testing. Oxford: OUP.

3. Bachman, L. F \& D. Palmer. (1996). Language Testing in Practice. Oxford: OUP.

4. Bander, R. G. (1978). American English Rhetoric. New York: Holt, Rinehart \& Winston.

5. Banerjee, J. (2003). Achievement Tests, in Byram, M. (ed.) Routledge Encyclopedia of Language Teaching and Learning. Routledge: London. 3.

6. Cumming, A. (1995). 'Introduction: The Concept of Validation in Language Testing', in Cumming, A. \& R. Berwick (eds). Validation in Language Testing. Philadelphia: Multilingual Matters. 1-14.

7. Cumming, A. \& D. Mellow. (1995). An Investigation into the Validity of Written Indicators of Second Language Proficiency, in Heaton, J. B. (ed.) Language Testing. London: Modern English Publications. 72-93.

8. Davies, A. (1982). Criteria for Evaluation of Tests of English as a Foreign Language, in Heaton, J. B. (ed.) Language Testing. London: Modern English Publications. 11-16.

9. Douglas, D. (2010). Understanding Language Teaching. Oxon: Routledge.

10. Foley, M. \& D. Hall. (2003). Advanced Learner's Grammar. Harlow: Longman.

11. Heaton, J. B. (1991). Writing English Language Tests. New York: Longman.

12. Jatautaite D., Kazimianec J. (2019). Visual Aids as a Part of Second Language Learning Strategies. Šiuolaikinès visuomenės ugdymo veiksniai: Mokslo žurnalas $=$ The Factors of Education in Modern Society / Vilnius : Generolo Jono Žemaičio Lietuvos karo akademija, IV t., 401 p. [M.kr.: S 007] ISSN 2424-6131 (Print); ISSN 2424-614X (on line)

13. Jatautaitė D, Kazimianec J., Aleksandrovič J. (2019) Bendradarbiavimo metodo taikymas anglų kalbos paskaitoje". Šiuolaikinès visuomenès ugdymo veiksniai: Mokslo žurnalas $=$ The Factors of Education in Modern Society / Vilnius: Generolo Jono Žemaičio Lietuvos karo akademija, 2019. IV t., 401 p. [M.kr. S 007]; ISSN 2424-6131 (Print); ISSN 2424-614X (on line)

14. Johnson, R. K. (1982). Questioning some Assumptions about Cloze Testing, in Heaton, J. B. (ed.) Language Testing. London: Modern English Publications. 59-72.

15. Hubbard, P., Jones, H., Thornton, B., \& R. Wheeler. 1983. A Training Course for TEFL. Hong Kong: OUP.

16. 
17. Lado, R. (1964). Language Testing: The Construction and Use of Foreign Language Tests. New York: McGraw-Hill Company.

18. Litwin, M. S. (1995). How to Measure Survey Reliability and Validity. Thousand Oaks: SAGE Publications.

19. McNamara, T. (2000). Language Testing. Oxford: OUP.

20. Moss, M. (2017). Acquiring and Processing Morpheme Constructions: The MultiRep Model, in Evers-Vermeul, J. \& E. Tribushinina. Usage-based Approaches to Language Acquisition and Language Teaching. Berlin: De Gruyter Mouton 143-168.

21. Underhill N. (1982). The Great Reliability/Validity Trade-off: Problems in Assessing the Productive Skills, in Heaton, J. B. (ed.) Language Testing. London: Modern English Publications. 17-23.

22. Wall, D. \& J. Ch. Alderson. (1995). Examining Washback: The Sri Lankan Impact Study, in Cumming, A. \& R. Berwick (eds.) Validation in Language Testing. Philadelphia: Multilingual Matters. 194-221. 